\title{
Factors Influencing the Participation in Defined Contribution Pension Scheme by the Urban Unorganized Sector in India
}

\section{Amlan $\mathbf{G}^{*}$ and Shrutikeerti K}

Department of Management Studies, National Institute of Technology, India

\begin{abstract}
The present study is focused towards understanding the financial behavior of unorganized workers about the various old age pension schemes provided by the Government of India, and their willingness to participate for voluntary contribution for old age. This paper has comprehensively analysed the issues related to New Pension Schemes (NPS) and highlights the appropriate gaps in the system through an empirical study in Burdwan District, West Bengal, India.

The present study assesses the overall awareness level of NPS products and the factors that influence the individual behavior regarding everyday financial decisions. The study further examines the relative significance of these factors on voluntary participation in the NPS and finds that future financial concern and financial advice are very important factors that influence the decision making of the individuals. But the financial literacy is pivotal for awareness of the availability of such schemes for old age security.
\end{abstract}

Keywords: Social security; Pension; Unorganized sector; NPS; Financial Literacy

\section{Introduction}

The change in the demographic pattern of the economies particularly developing ones with the advent of time, have created an important concern for the population of those countries as well as the authorities and policy makers. Rise in population with increased rate of life expectancy has called for social security concerns, especially in the Asian economies such as China and India.

Since India is the second most populated country in the world with maximum young population at present, it is going to have a high proportion of elderly population in coming years. As per the population census of India, 2011, the elderly populations (60+ years) consist of almost $9 \%$ (100 million) of the total population. According to the estimates by the United Nations Population Fund (UNFPA) and Help Age International in 2012, the number of elderly population is expected to increase to 323 million which is $20 \%$ of the total population of India by 2015 [1]. The country therefore has a tremendous burden of providing old age security besides issues regarding income and employment in advancing years with other social security measures like unemployment relief. The increasing dependency ratio brings more economic pressure on the economy which ultimately has an impact on financial expenditures on social security measures. The old age dependency ratio in India has increased from $13.1 \%$ in 2001 to $14.2 \%$ in 2011.

Pension coverage in India has mainly been based financed through employer and employee participation. As a result, the major retirement benefits are mostly been restricted to the organized sector which constitutes about $10 \%$ of the total working population. Rest $90 \%$ worker who are in unorganized sector are not cover under the ambit of any social security system [2].

Although there have been some old age security schemes in India however an important feature of these schemes is that, these are based on Defined Benefit system which poses a great burden on the exchequer. To reduce this burden, National Pension System (NPS), which is based on Defined Contribution (DC) system, was introduced in January 2004 for civil servants only (except armed forces) but subsequently it was open for all the citizens of India under All Citizens Scheme in May
2009 and introduced the Swavalamban Scheme under NPS which is a Defined Contribution (DC) voluntary pension scheme exclusively for the people of the unorganized sector in 2010. There have been five years since the launch of the NPS Swavalamban Scheme and the participation rate of the unorganized sector in this scheme is insignificant.

This raises the question of whether the scheme is actually meeting its purposes. Is it covering the unorganized sector to provide them the low cost pension benefit and achieve the broad agenda of financial inclusion? Our study aims to find the answers of these questions and study has been organised in the following manner. The following next two sections would deal with the present pension structure of India and reforms in the Indian pension system along with the literature on defined contribution pension system in unorganised sector. In the fourth section we would analyze the primary data to study the voluntary pension system in urban (sub urban) unorganized sector followed by findings.

\section{The Indian pension sector}

The old age pension scheme in India can be traced back to 1881 when the Royal Commission on Civil Establishments started giving pension benefits to the government employees during British rule. Since then, the concept of pension was incepted. With the advent of time, Indian Government Acts made further provisions in 1919 and 1935 [2]

Schemes like General Provident Fund (GPF) under Workmen Compensation Act, 1923 was launched followed by Coal Mines Provident Fund Scheme in 1945 for the coal mine employee,

*Corresponding author: Amlan G, Department of Management Studies, National Institute of Technology, India, Tel: 9434110206;; E-mail: amlanpost@gmail.com

Received December 18, 2015; Accepted January 19, 2016; Published January 22, 2016

Citation: Amlan G, Shrutikeerti K (2016) Factors Influencing the Participation in Defined Contribution Pension Scheme by the Urban Unorganized Sector in India. J Glob Econ 4: 176. doi:10.4172/2375-4389.1000176

Copyright: $\odot 2016$ Amlan G, et al. This is an open-access article distributed under the terms of the Creative Commons Attribution License, which permits unrestricted use, distribution, and reproduction in any medium, provided the original author and source are credited. 
Employees' Provident Fund Scheme (EPFS) 1952, Assam Tea Plantation Employees' Provident Fund Scheme in 1955, Employees' Pension Fund Scheme in 1955. A brief overview of old age pension system in India is given in Table 1.

An analysis of the table shows that till 2004 most of the pension schemes were based on Defined Benefit system that was creating an excessive burden on the exchequer. The EPS was underfunded and the expenditure of Government on account of civil servants pension was also high, [3]. Government of India had more than $64 \%$ of GDP, as the implied pension debt on account of civil servants [4]. The other problem with the Indian pension sector was its low coverage. According to the Old Age Social and Income Security (OASIS) report, the working population which was eligible to participate in the formal pension system was less than $11 \%$ [5]. In addition to this around $28 \%$ of the salaried workforce and around 268 million workers in the unorganized sector like farmers, shopkeepers, taxi drivers were not included in those schemes as per the existing provisions. Therefore approximately $90 \%$ of the workforce of the country was not covered under any scheme to provide for social security.

In order to address these issues, National Pension System (NPS) was introduced in January 2004 on the lines of Old Age Social and Income Security (OASIS) proposal which is based on Defined Contribution (DC) system [5]. It is administered by the interim Pension Fund Regulatory and Development Authority (PFRDA). Initially the scheme was for civil servants only (except armed forces) but subsequently it was open for all the citizens of India under All Citizens Scheme in May 2009. The scheme is therefore based on the third pillar as per the five pillar system promoted by World Bank for the post retirement security.

Even after the reforms were introduced the coverage of pension was very low in the unorganized sector that constitutes a major proportion of the working population shown in Table 2.

As per the $55^{\text {th }}$ round of National Sample Survey (NSS), out of the total employment the proportion of unorganized workers was $86.34 \%$ in 1999-2000. This situation remained the same in 2004-2005 under the $61^{\text {st }}$ round [6]. Considering this situation the Government of India introduced the Swavalamban Scheme under NPS in 2010, which is a Defined Contribution (DC) voluntary pension scheme exclusively for the people of the unorganized sector. For this purpose, the unorganized sector was redefined. It includes all those persons who are not in regular employment of the Central or State Government or not working in an autonomous body of central or state government with employer assisted retirement benefit scheme, or not covered by any social security scheme like EPF and Miscellaneous Provisions Act, 1952 or Seamen's Provident Fund Act, 1966, or Coal Mines Provident Fund and Miscellaneous Provisions Act, 1948, or Assam Tea Plantations Provident and Pension Fund Scheme Act, 1955 and the Jammu and Kashmir Employees' Provident Fund Act, 1961 [6].

In order to attain this panoptic agenda of financial inclusion and hence to encourage the people to save under this scheme, it was launched with the following features:

- Any person can join the scheme with a minimum contribution of Rs 1000 in a year and maximum Rs 12000 in a year.

- The Government contributes Rs 1000 per year to every NPS Swavalamban account

- After attaining sixty years of age, at least $40 \%$ of the total corpus is used to buy a life annuity plan that provides a monthly a pension to the subscriber.

- It is a low cost pension scheme under which there are no charges for registration and further contribution.

There have been five years since the launch of the NPS Swavalamban Scheme. This raises the question of whether the scheme is actually meeting its purpose of covering the unorganized sector to provide them the low cost pension security and achieve the broad agenda of financial inclusion. Our study aims to find the awareness and participation of unorganised sector and also analyse the financial behaviour of this

\begin{tabular}{|c|c|}
\hline $\begin{array}{l}\text { Civil Servants Pension } \\
\text { Scheme }\end{array}$ & $\begin{array}{l}\text { Central and State Government Employees, based on Defined Benefit system for those who joined before 2004. After 2004, it is based on } \\
\text { Defined Contribution system. }\end{array}$ \\
\hline EPFO Scheme & Launched in 1952, it covers formal sector workers whose monthly earnings are Rs 6500 or below and firms with 20 or more members \\
\hline $\begin{array}{l}\text { Occupational Pension } \\
\text { Schemes }\end{array}$ & $\begin{array}{l}\text { The schemes are now based on Defined Contribution system, however the mode of pension payment in such schemes depends on } \\
\text { enterprise to enterprise }\end{array}$ \\
\hline Public Provident Fund & $\begin{array}{l}\text { Based on Defined Contribution system it is a voluntary scheme for all citizens started in } 1968 \text {. } \\
\text { Participation to this scheme provides tax benefit to its members, so it mainly draws in formal sector workers who come in under the tax slab. }\end{array}$ \\
\hline $\begin{array}{l}\text { The Indira Gandhi } \\
\text { National Old Age } \\
\text { Pension } \\
\text { Scheme }\end{array}$ & $\begin{array}{l}\text { Launched in 1995, it is based on Defined Benefit system and covers the people who are } 65 \text { years (later reduced to } 60 \text { years) or above and lie } \\
\text { below poverty line. Pension payments include Rs } 200 \text { per month from the Central Government plus the State Government's contribution that } \\
\text { depends on State to State. }\end{array}$ \\
\hline $\begin{array}{l}\text { National Pension } \\
\text { Scheme }\end{array}$ & $\begin{array}{l}\text { Based on Defined Contribution system it covers all new entrants of Central Government (except armed forces) who have joined the service on } \\
\text { or before } 1 .\end{array}$ \\
\hline $\begin{array}{l}\text { NPS: Swavalamban } \\
\text { Scheme }\end{array}$ & $\begin{array}{l}\text { January } 2004 \text {. The scheme was later made open for all the citizens who would like to voluntarily contribute. Launched in } 2010 \text {, the scheme is } \\
\text { basically for the unorganized sector workers. Although it is based on Defined Contribution, yet in order to encourage } \\
\text { participation in the scheme, the Government the } \\
\text { Government contributes Rs } 1000 \text { per annum to each Swavalamban account. }\end{array}$ \\
\hline
\end{tabular}

Source: EPFO, PFRDA, Sanyal and Singh (2013)

Table 1: Pension schemes in India

\begin{tabular}{|l|c|c|c|}
\hline NSS ROUND & $\begin{array}{l}\text { Total Employment (in } \\
\text { millions) }\end{array}$ & $\begin{array}{l}\text { Workers in Formal(Organized sector) in } \\
\text { Percent }\end{array}$ & $\begin{array}{l}\text { Workers in Informal sector (Unorganized sector) in Per } \\
\text { cent }\end{array}$ \\
\hline $55^{\text {th }}$ round (1999-2000) & 396.8 & 13.66 & 86.34 \\
\hline $61^{\text {st }}$ round (2004-2005) & 457.5 & 13.66 & 86.34 \\
\hline
\end{tabular}

Source: Economic Survey, Ministry of Finance, GOI

Table 2: Working population in Organised and Unorganised sector in India 
specific sector. The paper is organized as follows: Section I gives the introduction, Section II gives a brief review of literature, Section III describes the data and methodology and Section IV discusses results and important implications from it.

\section{Literature Review}

\section{Informal sector and poverty and social security}

Expressing the concern for the weak informal sector in the developing countries, Canagarajah and Sethuraman find that the workers in this sector constitute a major part of the employed population who are without any cover of social security in India [7]. If this major proportion of the sector is taken into consideration, then their contribution to the Gross Domestic Product is also noteworthy in many developing countries, Blunch et al. [8]. The informal sector accounts for about $28 \%$ of the GDP while in India $32.4 \%$ of the GDP are contributed by the informal sector which is worth considerable $[9,10]$. According to Canagarajah and Sethuraman informal accounted for $77 \%$ of the net domestic product and it is not under any social security cover [7].

Although the informal sector accounts for a major share in the GDP, yet a considerable portion of its workers are more inclined towards poverty, for example the study by Sethuram finds that most of the Latin American poor workers belong to the informal sector. It was found as high as $87.1 \%$ in Panama, $66.4 \%$ in Brazil, $66.2 \%$ in Bolivia [11]. In fact the relative frequency of poverty is found very high in the informal sector. In India also the situation is not much different than the other countries mentioned above. A large proportion of poor people in India correspond to informal sector and about $47 \%$ of the workers in the informal sector were poor [12].

For poor, contributing to pension scheme creates welfare loss as they have very little income in their hands to support even the basic necessities of life [13]. The argument in favour relates to the high mortality rate of poor people during old age. Due to this fact they don't want to defer the consumption of their income by contributing in the pension scheme since they are not sure of whether they will be alive in those advancing years of life. This contributes to another reason for low social security in the informal sector.

In addition to this, majority of the poor people in this sector still give more importance to old system of social security. This relates to having big families or having a male child for their support in the old age [14]. They also depend on remittances from their family members who migrate to different places $[14,15]$. Other reasons for nonparticipation of informal workers relate to weak laws and rules due to which the workers who do not find the schemes advantageous can easily escape from it. They do not want to participate in these schemes for many reasons that include earning below the minimum wage rate.

\section{Informal sector and financial literacy and social security}

Pension reforms in India require individuals from unorganised sector to decide whether to participate in pension funds or not and if they thought of participating in the voluntary defined contribution pension schemes then how much to contribute. Another important aspect in investing in these pension schemes is their ability to deal with financial matters. Almost all the studies, in developed and developing countries, found that the financial literacy has a Positive causal and significant impact on the probability of participating in defied pension plans [16-20]. Studies are also found that the most individuals lack knowledge of basic concepts such as interest rates and inflation and risk diversification $[16,21]$.
Thus the informal sector is not under social security cover for many reasons, major being earning low level of income to support present consumption and low level of formal education. This raises huge concern for the survival and development of this population in old age. Realising the importance of this issue, our study has tried to find the participation of informal sector in India particularly towards Swavalamban Scheme under National Pension System. We aim to understand how people are contributing towards securing future income for their old age with respect to different aspects of their financial decisions taken by them. The two main broad objectives of our study are,

- To find the awareness and participation in the NPS Swavalamban Scheme

- To find the factors that play an important role while taking financial decision

\section{Data and Methodology}

This study is based on a primary survey done in the Burdwan district, of West Bengal in India to capture the demographic information, financial decision making behavior with regard to NPS- Swavalamban scheme by the urban unorganised sector. A concrete non random sample of 400 workers from unorganized sector was taken [22]. The responses were recorded with the help of a questionnaire, designed to explore the financial decision making of unorganized sector towards financial products. The research techniques include Factor Analysis in order to find the factors that play an important role while taking financial decision followed by Reliability testing. Further Multi-co linearity test was also done in order to check if there are any problems of multi-co linearity among the factors.

\section{Results}

The demographic profile of the sample shows that the majority of the people are literate (77.7\%) in the urban area of India with $46.36 \%$ under-graduate. However, $62.33 \%$ of the people do not have any knowledge about the NPS Swavalamban Scheme while the rest $17.67 \%$ only did know about the scheme shown in Figure 1. Majority of these people from our sample having income range between Rs 5,000 to Rs 10,000 (i.e., approximately $\$ 80$ to $\$ 150$ ) per month shown in Figure 2

While analysing the primary data we first checked the significance level of our variables with the help of Bartlett's test of Sphericity which shown in Table 3 the significance level is less than 0.05 . This confirms that the variables have patterned relationships and therefore factors exist in the dataset. In case of the KMO (Kaiser-Meyer-Olkin) test, we get the score is 0.724 which indicates that our sample size is good enough for performing factor analysis.

For determining the number of significant factors, Principal Component Analysis have been used and the Total Variance Explained by each factor is provide in Table 4 . The table has factors arranged in the descending order starting from the factor that explains the highest variance followed by the lower variance explaining factor. As a conventional rule Eigen Values less than 1 are not considered. In our results we have four significant factors that explain $76.25 \%$ of the variance. The Screen Plot (Figure 3) also confirms that there are four significant factors.

The factor loadings in our results show that the factors are fairly desirable with at least two variables per factor that are above 0.5. (Appendix I, Rotated Component Matrix) 


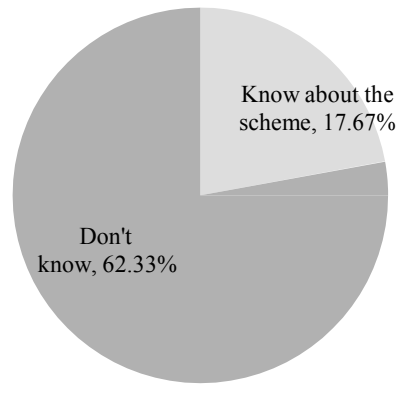

Source: Primary data collected by the author

Figure: 1: Awareness level of NPS

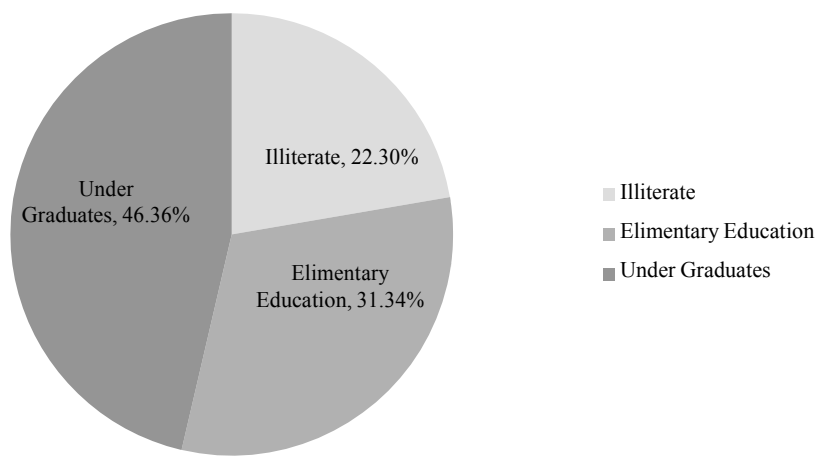

Source: Primary data collected by the authors

Figure 2: Literacy Level

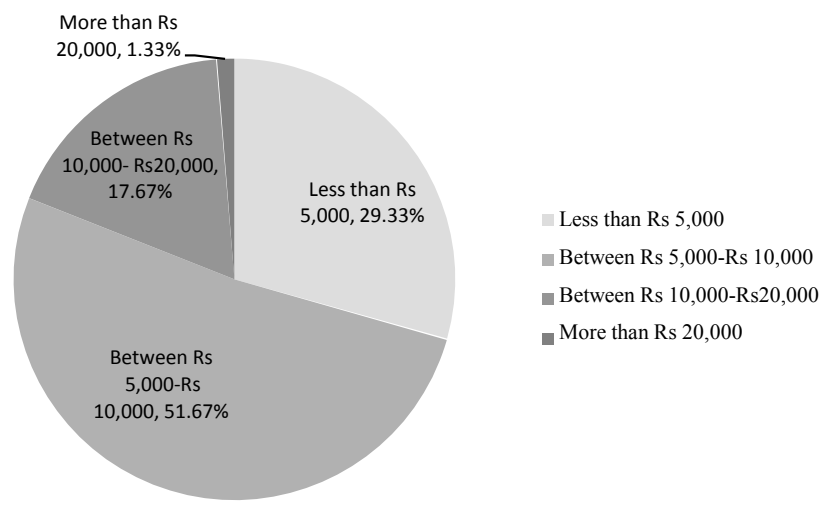

Source: Primary data collected by the authors

Figure 3: Income Level

\begin{tabular}{|l|l|}
\hline Kaiser-Meyer-Olkin Measure of Sampling Adequacy & .724 \\
\hline Approx. Chi-Square & 3017.534 \\
\hline Bartlett's Test of Sphericity Df & 91 \\
\hline Sig. & .000 \\
\hline
\end{tabular}

Table 3: KMO and Bartlett's Test

The factor loadings in our result show that our factors are fairly desirable with at least 2 variables per factor that are above 0.5 . Finally the four identified factors were renamed, as follows,

To sum up we have defined our four factors which are:
Factor 1: Income based decisions

Factor 2: Financial Advice

Factor 3: Concern for future

Factor 4: Risk Taking Ability

These four factors were found to be significant that account for a total of $76.25 \%$ variance. These factors are strongly interlinked with the attitude towards financial decision taking. According to the analysis the variables associated with the factors are shown in Table 5.

For testing the reliability of the questionnaire, reliability tests (Chronbach's Alpha) were conducted on each factor and the results in Table 6 show that Chronbach's Alpha varies from .803 to .907 for all the factors. Therefore the questionnaire has high reliability. For exploring the decision making of the individuals, the relationship among variables should be contemplated. This is done by factor analysis which recognizes the essential factors which help in finding any correlation within a set of observed variables.

In order to further know the accuracy of our results, we have performed multi-collinearity tests. The results show that the Durbin Watson statistic does not indicate any auto correlation (Appendix II). Variance Inflation Factors (VIF) for all five factors are also less than five which does not indicate any multi-collinearity problem (Appendix II).

\section{Conclusions}

The demographic profile of the people in the sample shows that most of the people are literate however their awareness level about the scheme is as low as $17.67 \%$. This clearly shows that the financial literacy about the old age pension schemes is too low in India. Therefore, participation in these voluntary pension schemes is also low at this point of time.

One of the important findings of this study is about their financial decision making process. People from the urban unorganized sector take their financial decision mostly based on the advices from friends and family members and public information in the form of advertisements. The results show that people do give importance to the advertisements about the financial products (factor loading .922) more than taking financial advices from financial experts. This is probably due to their lower income base which does not allow them to afford to take such services from the financial experts. Moreover, it is not in much practice or in vogue to take the financial expert's opinion in India. This clearly shows that NPS Swavalamban scheme is not well advertised to reach those who need to be benefitted from it.

Although people have concern for future with fear of no job in old age (factor loading .922), concern for future income (factor loading.953), for meeting social and family obligations (factor loading .862), yet they are not able to create provisions for it. They do engage in financial transactions (factor loading .892) but they make spontaneous purchase (factor loading .898) which shows that even if they buy financial products, they do so without having much knowledge of it.

We find that financial literacy in old age social security is significant factor in improving the voluntary pension scheme (NPS) in India and therefore, serious attention is needed to increase the financial literacy level of the people so that they are able to take their financial decisions based on the available financial products such as NPS for their old age security. Places where most people are engage in financial transactions like banks, post offices, NGOs, Panchayats, Municipalities etc should 
Citation: Amlan G, Shrutikeerti K (2016) Factors Influencing the Participation in Defined Contribution Pension Scheme by the Urban Unorganized Sector in India. J Glob Econ 4: 176. doi:10.4172/2375-4389.1000176

Page 5 of 6

\begin{tabular}{|c|c|c|c|c|c|c|c|c|c|}
\hline \multirow[t]{2}{*}{ Component } & \multicolumn{3}{|c|}{ Initial Eigen values } & \multicolumn{3}{|c|}{ Extraction Sums of Squared Loadings } & \multicolumn{3}{|c|}{ Rotation Sums of Squared Loadings } \\
\hline & Total & $\%$ of Variance & Cumulative $\%$ & Total & $\%$ of Variance & Cumulative \% & Total & $\%$ of Variance & Cumulative $\%$ \\
\hline 1 & 3.508 & 25.059 & 25.059 & 3.508 & 25.059 & 25.059 & 3.447 & 24.623 & 24.623 \\
\hline 2 & 2.93 & 20.928 & 45.987 & 2.93 & 20.928 & 45.987 & 2.858 & 20.412 & 45.035 \\
\hline 3 & 2.847 & 20.334 & 66.321 & 2.847 & 20.334 & 66.321 & 2.555 & 18.246 & 63.282 \\
\hline 4 & 1.39 & 9.932 & 76.254 & 1.39 & 9.932 & 76.254 & 1.816 & 12.972 & 76.254 \\
\hline 5 & 0.904 & 6.455 & 82.709 & & & & & & \\
\hline 6 & 0.728 & 5.198 & 87.907 & & & & & & \\
\hline 7 & 0.332 & 2.369 & 90.276 & & & & & & \\
\hline 8 & 0.29 & 2.074 & 92.35 & & & & & & \\
\hline 9 & 0.278 & 1.985 & 94.335 & & & & & & \\
\hline 10 & 0.232 & 1.66 & 95.995 & & & & & & \\
\hline 11 & 0.226 & 1.612 & 97.607 & & & & & & \\
\hline 12 & 0.199 & 1.422 & 99.028 & & & & & & \\
\hline 13 & 0.074 & 0.532 & 99.56 & & & & & & \\
\hline 14 & 0.062 & 0.44 & 100 & & & & & & \\
\hline
\end{tabular}

Extraction Method: Principal Component Analysis

Source: Calculated with SPSS

Table 4: Total Variance Explained

\section{Factors}

Factor 1 (Income based decisions)

Factor 2 (Financial Advice)

Factor 3 (Concern for future)

Factor 4 (Risk Taking Ability)

\section{Associated Variables}

1-Income is insufficient to save regularly, Most part of the income is spent

2-Don't have regular income to save

3-Postpone purchase if insufficient income

4- Save only small portion of income

1-Advertisements about financial scheme

2-Take family's advice on financial matters

3-Take advice from friends on financial matters

4-Take advice of financial experts

1-Concern about future income

2-Fear of no job in old age

3-Meeting social and family obligations

1- Spend spontaneously even in large purchase 2- Engage in financial transactions

\begin{tabular}{|c|c|}
\hline Constructs & Chronbach's Alpha \\
\hline Factor 1 & .884 \\
\hline Factor 2 & .853 \\
\hline Factor 3 & .917 \\
\hline Factor 4 & .803 \\
\hline
\end{tabular}

Table 6: Reliability Tests

be involved in this regard to achieve the broad agenda of financial inclusion, the purpose for which NPS Swavalamban Scheme was launched. We need an all-round efforts from all the stakeholders to improve financial literacy which can be pivotal to the expansion of the use of such social security financial products.

\section{References}

1. United Nations Population Fund (UNFPA) (2012) Ageing in twenty first century: A celebration and a challenge. UNFPA and HelpAge International, New York, USA.

2. Goswami R (2001) Indian Pension System: Problems and Prognosis. IAA Pensions Seminar, Brighton.

3. Dave S (2006) India's pension reform: A case study in complex institutional change.

4. Bhardwaj G, Dave S (2006) Towards estimating India's implicit pension debt. Invest India Economic Foundation.

5. The Project Old Age Social and Income Security (OASIS) Report (2000). Ministry of Social Justice and Empowerment. Government of India.

6. Sadhak H (2013) Pension Reform in India: The Unfinished Agenda. Sage Publications, India.
7. Canagarajah S, Sethuraman SV (2001) Social protection and the informal sector in developing countries: Challenges and opportunities. The World Bank.

8. Niels-Hugo B, Canagarajah S, Raju D (2001) The informal sector revisited: A synthesis across space and time. World Bank.

9. Charmes J (1999a) Informal sector, Poverty and Gender. A Review of Empirical Evidence. The World Bank.

10. Charmes J (1999b) Gender and Informal Sector, Contribution to the World's Women 2000. Trends and Statistics, United Nations.

11. Sethuraman SV (1997) Urban Poverty and the Informal Sector: A Critical Assessment of Current Strategies. International Labour Organisation.

12. Pradhan BK, Roy PK, Saluja MR (1999) Informal Sector in India: A Study of household Saving Behaviour. National Council of Applied Economic Research.

13. Holzmann R, Packard T, Cuesta J (2000) Extending coverage in multi-pillar pension systems : Constraints and hypotheses, preliminary evidence and future research agenda. The World Bank.

14. Hoddinott J (1992) Rotten Kids or Manipulative Parents: Are Children Old-Age Security in Western Kenya?. Economic Development and Cultural Change 40: 545-66.

15. Lucas EB, Stark O (1985) Motivations to Remit: Evidence from Botswana Journal of Political Economy 93: 901-918.

16. Fornero E, Monticone C (2011) Financial literacy and pension plan participation in Italy. Journal of Pension Economics and Finance 10: 547-564.

17. Sekita S (2011) Financial literacy and retirement planning in Japan. Journal of Pension Economics and Finance 10: 637-656.

18. Alessie R, Rooij MV, Lusardi A (2011) Financial literacy and retirement preparation in the Netherlands. Journal of Pension Economics and Finance 10: $527-545$. 
Citation: Amlan G, Shrutikeerti K (2016) Factors Influencing the Participation in Defined Contribution Pension Scheme by the Urban Unorganized Sector in India. J Glob Econ 4: 176. doi:10.4172/2375-4389.1000176

Page 6 of 6

19. Klapper L, Panos GA (2011) Financial literacy and retirement planning: the Russian case. Journal of Pension Economics and Finance 10: 599-618.

20. Bucher-Koenen T, Lusardi A (2011) Financial literacy and retirement planning in Germany. Journal of Pension Economics and Finance 10: 565-584.
21. Almenberg J, Save-Soderbergh J (2011) Financial literacy and retirement planning in Sweden. Journal of Pension Economics and Finance 10: 585-598.

22. Krejcie RV, Morgan DW (1970) Determining sample size for research activities. Educational and Psychological Measurement 30: 607-610. 